\title{
Transient deficits after inadvertent intrathecal trigger-point injection with lidocaine
}

Figure $1 \quad$ Air in the ventricular system

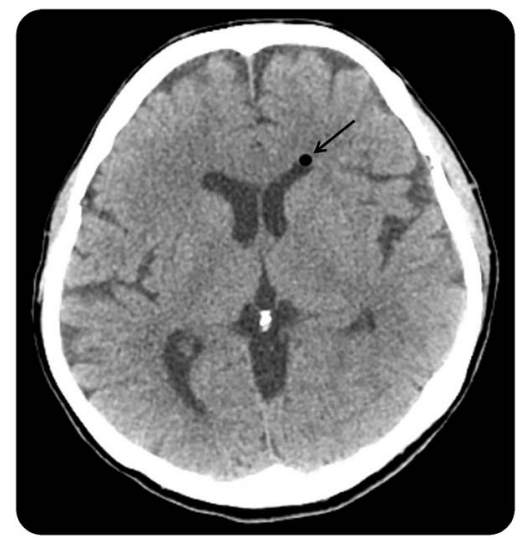

Noncontrast CT of the brain shows air inclusion in the anterior horn of the left lateral ventricle (black arrow).

A 43-year-old woman had trigger-point injections for chronic neck pain by a traditional Chinese medicine physician. Paravertebral muscles at C5-C6 were infiltrated with lidocaine. Thirty minutes later, right-sided hemiparesis with nystagmus, dysarthria, and anisocoria developed. The patient complained of vertigo, vomited multiple times, and became somnolent. Neuroimaging revealed air in the ventricular system (figure 1) and in the dural sheath of the fifth cervical nerve root (figure 2), implying an accidental intrathecal injection and thus a possible direct effect of lidocaine. Three hours later, neurologic symptoms resolved gradually and the patient recovered fully. MRI revealed no intraparenchymal damage.

Figure 2 Air in the dural sheath of the fifth cervical nerve root

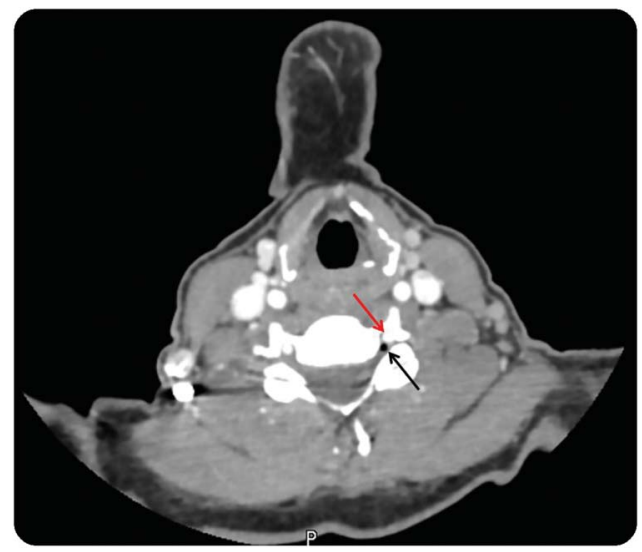

CT angiography reveals air inclusion in the dural sheath of the fifth cervical nerve root (black arrow), adjacent to the left vertebral artery (red arrow). 
From the Department of Neurology, Medical Centre, Hungarian Defence Forces, Budapest, Hungary.

Author contributions: Dr. Daniel Bereczki, Jr.: examination of the patient, collecting all clinical data, writing of the manuscript. Dr. Nora Peto: examination of the patient, critical review and revision of the manuscript for important intellectual content. Dr. Norbert Szegedi: examination of the patient, critical review and revision of the manuscript for important intellectual content, supervision. Study funding: No targeted funding reported.

Disclosure: The authors report no disclosures relevant to the manuscript. Go to Neurology.org for full disclosures.

Correspondence to Dr. Bereczki: bereczki.daniel@hotmail.com
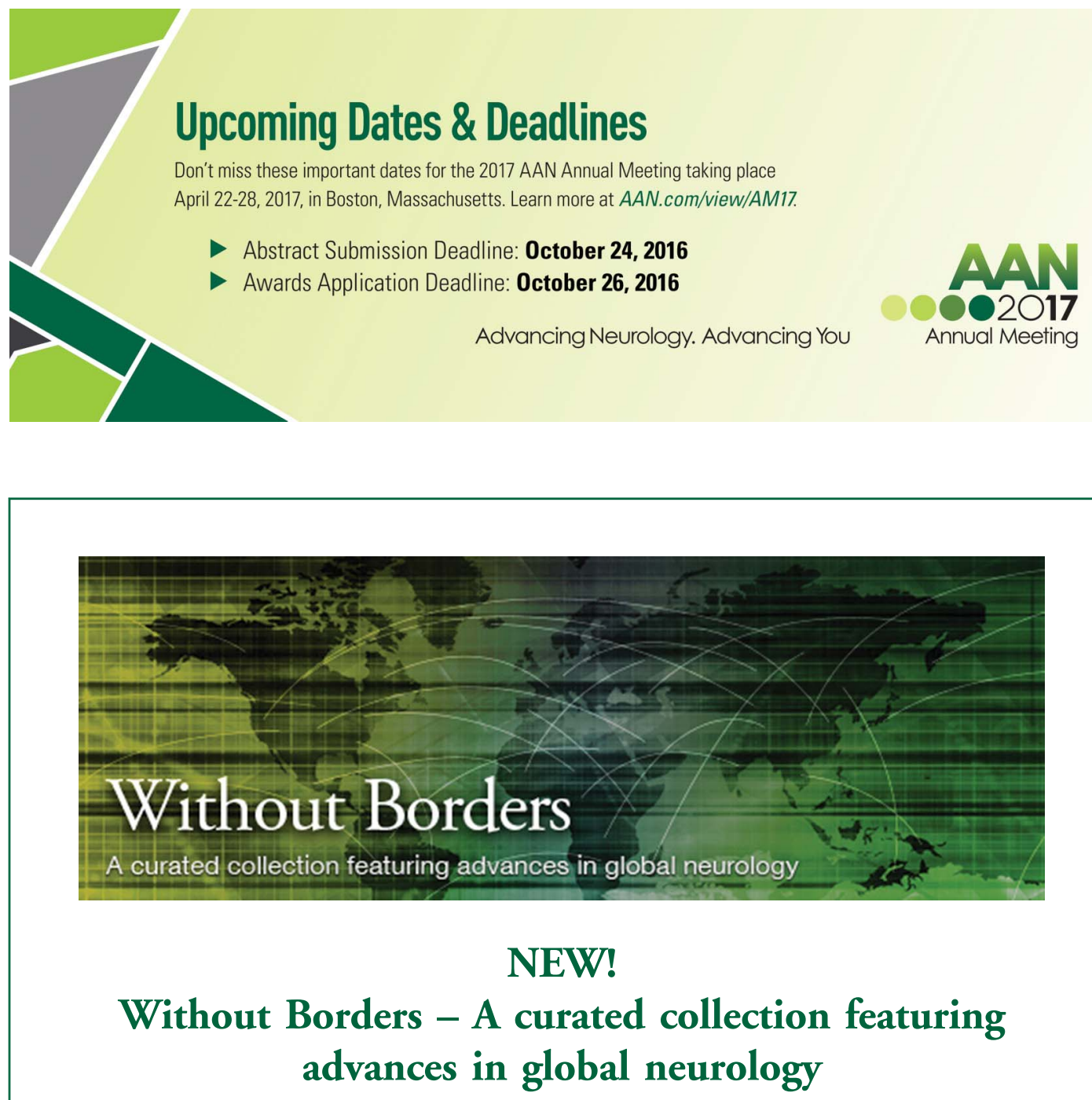

This Neurology ${ }^{\circledR}$ special interest Web site is the go-to source for tracking science and politics of neurology beyond the United States, featuring up-to-the-minute blogs, scholarly perspectives, and academic review of developments and research from Neurology journals and other sources. Curated by Gretchen L. Birbeck, MD, MPH.

Expand your world view at Neurology.org/woborders. 


\section{Neurology}

Transient deficits after inadvertent intrathecal trigger-point injection with lidocaine Daniel Bereczki, Jr, Nora Peto and Norbert Szegedi

Neurology 2016;87;848-849

DOI 10.1212/WNL.0000000000003015

This information is current as of August 22, 2016

$\begin{array}{ll}\begin{array}{l}\text { Updated Information \& } \\ \text { Services }\end{array} & \begin{array}{l}\text { including high resolution figures, can be found at: } \\ \text { http://n.neurology.org/content/87/8/848.full }\end{array} \\ \text { Subspecialty Collections } & \text { This article, along with others on similar topics, appears in the } \\ \text { following collection(s): } & \text { All Cerebrovascular disease/Stroke } \\ \text { http://n.neurology.org/cgi/collection/all_cerebrovascular_disease_strok } & \text { e } \\ & \text { All Pain } \\ & \text { http://n.neurology.org/cgi/collection/all_pain } \\ & \text { Cerebrospinal Fluid } \\ & \text { http://n.neurology.org/cgi/collection/cerebrospinal_fluid } \\ & \text { Information about reproducing this article in parts (figures,tables) or in } \\ & \text { its entirety can be found online at: } \\ & \text { http://www.neurology.org/about/about_the_journal\#permissions } \\ & \text { Information about ordering reprints can be found online: } \\ \text { hermissions \& Licensing } & \text { htt//n.neurology.org/subscribers/advertise }\end{array}$

Neurology ${ }^{\circledR}$ is the official journal of the American Academy of Neurology. Published continuously since 1951, it is now a weekly with 48 issues per year. Copyright () 2016 American Academy of Neurology. All rights reserved. Print ISSN: 0028-3878. Online ISSN: 1526-632X.

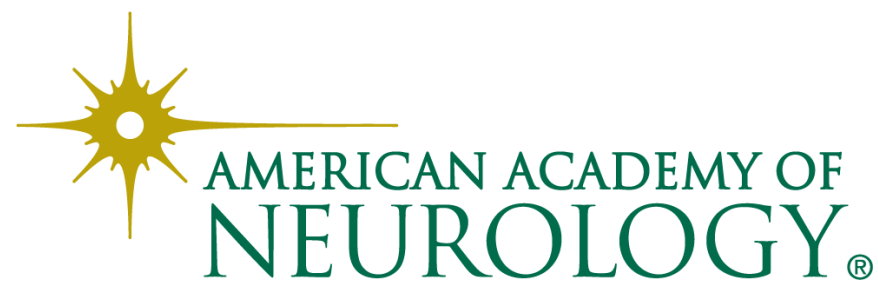

